\title{
Development of the Digital Economy in the Context of Improving the Methodological Support for the Formation and Assessment of Institutional Mechanisms of Innovation Activity
}

\author{
Denis Mironov, Viktor Blaginin, and Lyudmila Shaybakova \\ Ural State University of Economics, 620144 Ekaterinburg, Russia
}

\begin{abstract}
The practice of reforming macrosystems and attempts to transition from resource and industrial to digital economy showed that the lack of an institutional component increases information uncertainty, prevents the development of various forms of cooperation, increases the degree of risk in the implementation of exchange and contracting, causing an increase in economic, social and transactional costs, as well as higher prices for goods and services. The formation of institutional mechanisms of innovative development of the Russian Federation requires the development of appropriate scientific-methodological, regulatory and legal and information-analytical framework for effective regulation of the formation processes of high-tech economy, which is a pressing problem for our country. The paper identifies institutional factors, as well as areas to enhance and improve the effectiveness of innovation activities; established economic risks in an imperfect institutional environment; identified institutional components of the integration mechanism to ensure innovative economic development; proposed a methodological approach to assessing the quality of the institutional environment, as well as a diagnostic mechanism of its state.
\end{abstract}

\section{Introduction}

The concept of the digital economy is spreading around the world, including Russia. In 2017, the Russian government developed and approved a program to create the conditions for Russia's transition to a digital economy. The program includes five areas: human resources and education, information infrastructure, information security, the formation of research competencies and technological advances, and regulation. The innovative component is undoubtedly has a direct relevance to all five areas and is one of the key factors in their development.

However, in the transition from industrial to post-industrial (digital) economy, the formation of an innovative model of socio-economic development of the state requires the formation of an effective institutional environment to stimulate the integration of research and production sector to enhance innovation activity. We are talking about the system of effectively functioning state and non-state institutions of support and stimulation of 
innovative activity development; security of innovative sphere and implementation of its results; formation of intellectual, human, resource and venture financial and investment support of innovative activity. In the strategic perspective, economic development depends to a great extent not so much on the influence of economic levers, but on the level of development of the institutional basis of the economy.

The need to improve the institutional mechanisms of innovative development for countries with transformational economy due to the lack or low level of effectiveness of some important institutions of innovative development system, which leads to increased threats to economic security due to the deterioration of the country's place in the international division of labor, loss of position of domestic producers in the domestic market, technological lag and complication of conditions for the formation and effective use of knowledge, investment and innovation resources. The implementation of innovative model of economic development of the state, which has no alternative at the posttransformation stage is objective, determines the need for effective institutional mechanisms for reproduction, development and use of scientific, technological and innovative potential of the state, ensuring the active introduction of modern technologies into production activities, production and implementation of new types of competitive works, services, as well as technological solutions. The sum of the indicated factors has predetermined the relevance of the research topic.

The aim of the article is to study methodological approaches to the formation and assessment of institutional mechanisms of innovation, as well as the formation of methodological foundations for development in the context of improving their elements.

Elaboration of the problem degree. In general, theoretical studies of the institutional environment, mechanisms and tools for ensuring innovative development began in the late 19th century in the works of American economists T. Veblen (social and psychological institutionalism), J. Commons (social and legal institutionalism), W. Mitchell (conjunctural and statistical institutionalism).

Regarding the economic views of the founder of classical so-called "old" institutionalism T. Veblen, his theory is built on a number of contradictions between "business" and "industry. Giving industry an important role in the future, T. Veblen stressed that a technological intelligentsia, or "technocracy," would come to power. The scientist focused on the fact that the country should be led by representatives of industry, focused not on getting as much profit as possible, but on improving production technology and improving technical results [1].

The works of J. Galbraith, G. Colm, H. Heilbroner, G. Mundel, which laid the foundation for economic development in the context of the analyzed problem, became a further important evolutionary stage of approval of the foundations of institutionalism in the context of the analyzed problem. In Gilbert's work [2] a new term in economic science was introduced - "technostructure.

Revolutionary changes in the study of institutional mechanisms of innovative type of economic reproduction took place in the 80-90s of the twentieth century. The works of R. Coase, D. North, J. Buchanan, K. Menard are devoted to the study of the interaction between institutional structures and scientific and technological progress and their impact on ensuring the growth of social and economic effect. D. North proved that under the influence of transformation processes in institutional systems formal relations and institutional mechanisms are formed, increasing the efficiency of economic management at all levels of the system hierarchy of management and create the basis for the implementation of innovative model of structural adjustment and economic development. The elements of the institutional system, according to the scientist, are formal and informal institutions, enforcement mechanisms that ensure compliance with the rules [3, p. 17]. 
In C. Menard's work [4], he viewed the institutional mechanism as an association of partners to create an enterprise. The basis of the institutional mechanism operating within the organization, the scientist considered contractual relations, including a number of obligations, benefits and sanctions, arise between partners, grouped in a hierarchical coordination structure to achieve common goals.

Among domestic scientists a significant contribution to the coverage of the essence of the institutional mechanism was made by L. Abalkin, I. Afanasenko, O. Inshakov, S. Kirdina, G. Kleiner, N. Lebedeva, V. Makarov, R. Nureev, V. Plakhov, O. Sukharev, V. Tambovtsev, etc. In particular, in the works of L. Abalkin, the institutional mechanism is studied as a special subsystem of organizational and economic relations that provide social interactions [5]. O. Inshakov defines the analyzed category as a specific type of general economic mechanism, which should reflect the main structural, functional and genesis aspects of the functioning of the economic mechanism through formal institutions as the quality of law and order and protection of property rights [12].

To a certain extent, a similar interpretation of the institutional mechanism is held by $\mathrm{N}$. Lebedeva, who under the researched category understands the transformation system of disordered interrelations of economic subjects and agents in order to social order and fix their function, in accordance with the requirements of traditionally existing and legitimately established by society institutions, implemented in the spatial and temporal, structural and functional and historical and logical aspects of the genesis of the system-wide economic mechanism [6]. Thus, the institutional mechanism, on the one hand, is a structural component of the economic mechanism, which is characterized by a homogeneous system characteristic, and on the other hand is a complex system formation with a multicomponent structure of components, which covers the national economy, management of a set of organizational, legal and economic levers designed to ensure effective public policy.

\section{Research Methodology}

The research was conducted using elements of modern institutional economic theory; using elements of system and institutional approaches; using methods of system, logic and structural, technical and economic analysis, decomposition, expert assessments and text modeling.

\section{Practical Relevance, Suggestions and Research Results}

From the perspective of institutional economic theory, scientific and technological progress predetermines the need for state intervention in economic life in order to stimulate the development of education, science and technology, as well as reducing the risk of business activity, from the results of its implementation. At the same time, state participation in the regulation of the economy should be based on the principle of mutual solidarity between the subjects of the market, and not on direct intervention in their activities; limited only to planning at the state level, the management of state demand and redistribution of national income through fiscal mechanisms. According to this concept, the state and the private sector are considered as two independent subjects, the interaction of which should provide structural and innovative shifts in the economic system.

Generalization of methodological approaches to the formation of institutional mechanisms to ensure innovation activity of the state requires the allocation of institutional factors to strengthen the positive impact of the results of innovation activity to strengthen the innovation activity of the state, as well as overcoming the externalities of innovation activity in an imperfect institutional environment. This necessity is due to the dual 
influence of innovative activity on the innovative activity of the state. We are talking about the fact that innovation activity is not only a prerequisite for innovation activity of the state by implementing its results in the real sector of the economy and social sphere, but also causes increased risks and threats to innovation activity, especially in countries characterized by insufficient development of the institutional environment.

Table 1. Directions for enhancing and improving the efficiency of innovation and its externalities in an imperfect institutional environment.

\begin{tabular}{|c|c|}
\hline \multicolumn{2}{|c|}{ Implementation of the results of innovation in the real economy and social sphere } \\
\hline Measures of implementation & Institutional factors \\
\hline 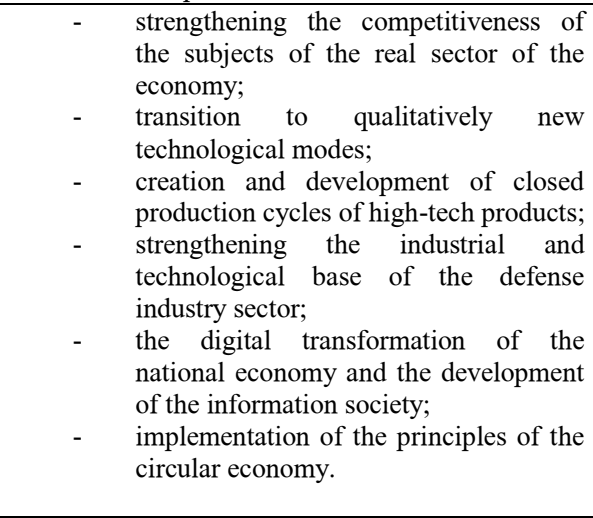 & 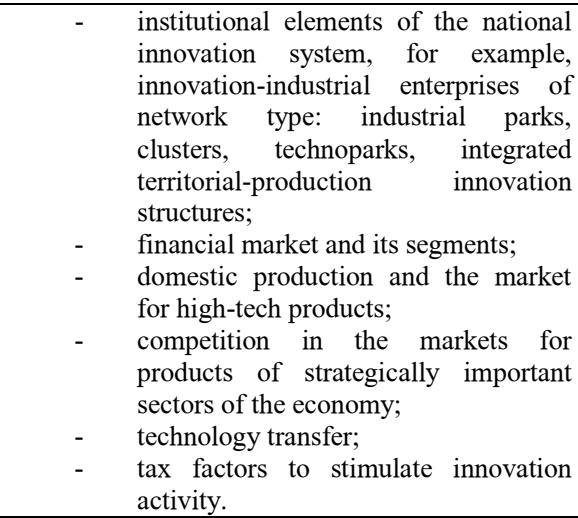 \\
\hline \multicolumn{2}{|c|}{ Externalities of innovation in an imperfect institutional environment } \\
\hline Risks & Institutional factors \\
\hline $\begin{array}{l}\text { - } \quad \text { "brain drain," "patent migration; } \\
\text { - } \quad \text { financing of quasi-innovative activities; } \\
\text { demotivation to innovative activity } \\
\text { through monopoly position in the } \\
\text { market; } \\
\text { development of "offshore" outsourcing } \\
\text { in IT and R\&D; } \\
\text { strengthening of the institutional "gap" } \\
\text { in the system of subjects from } \\
\text { generation to commercialization of } \\
\text { innovations; } \\
\text { shadowing of economic relations in the } \\
\text { sphere of innovations and their } \\
\text { financing; } \\
\text { the development of non-environmental } \\
\text { technologies. }\end{array}$ & 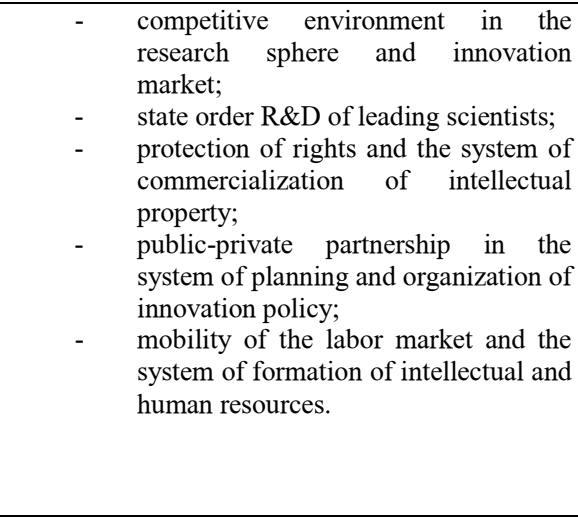 \\
\hline
\end{tabular}

As we can see, institutional factors, on the one hand, increase the positive impact on strengthening the innovative activity of the state. On the other hand, institutional factors are designed to overcome or minimize the externalities of innovation.

\section{Elements of the Integration Mechanism of Innovative Economic Development}

When analyzing the components of the mechanism of institutional support for innovation development, the approach of A. Carroll and A. Butchholtz deserves attention, which identifies the following components: political (improvement of institutional and legal mechanisms to ensure the formation of an effective system of public administration, which would exercise regulatory influence on the subjects of innovation, creating incentives for investment in innovation), economic (formation of effective financial incentives to attract 
investment resources in innovative processes, creation of institutional conditions for the development of innovative infrastructure, research and technological cooperation in innovation (development of social institutions and social investment, public involvement in the implementation of state innovation policy) and technological (introduction of modern technologies in production activities, production and sale of new types of competitive products) [8, p. 5].

At the same time, a generalized analysis of the literature allowed to form the author's system of components of the generalized mechanism of institutional support of intellectual and innovative economic reproduction: 1) mechanisms to support the initial development of innovative projects; 2) organizational and legal mechanisms of intellectual and innovative development; 3) mechanisms of state support and incentives; 4) mechanisms of financial and economic development (provision of financial resources and management of financial flows, etc.); 5) mechanisms of information support (cooperation, unified technological links, international scientific and technological cooperation, etc.); 6) mechanisms of research support (development of the system of education and professional, increasing the importance of intellectual and environmental awareness of society, etc.).

Table 2. Institutional components of the integration mechanism to ensure innovative economic development

\begin{tabular}{|c|c|c|c|}
\hline Goal & Elements & Functions & Instruments \\
\hline \multicolumn{4}{|c|}{ System of support for the initial development of innovative projects } \\
\hline $\begin{array}{l}\text { Creation of favorable } \\
\text { conditions for the } \\
\text { production of } \\
\text { innovative products with } \\
\text { high level of added } \\
\text { value. }\end{array}$ & $\begin{array}{l}\text { Innovation centers; } \\
\text { investment and venture } \\
\text { capital funds. }\end{array}$ & $\begin{array}{l}\text { Risk financing } \\
\text { innovative projects } \\
\text { small business; } \\
\text { development } \\
\text { knowledge-intensive } \\
\text { industries } \\
\text { through global } \\
\text { innovation } \\
\text { networks. }\end{array}$ & $\begin{array}{l}\text { Formation of regional, } \\
\text { interregional, } \\
\text { transnational industrial } \\
\text { clusters; deepening of } \\
\text { innovative division of } \\
\text { labor. }\end{array}$ \\
\hline \multicolumn{4}{|c|}{ Organizational support system } \\
\hline $\begin{array}{l}\text { Legislative and } \\
\text { infrastructural support of } \\
\text { the innovation process }\end{array}$ & $\begin{array}{lr}\text { Supervisory } & \text { bodies; } \\
\text { legislative bodies; } \\
\text { logistics } & \text { centers; } \\
\text { marketing } & \text { structures, } \\
\text { utilities, } & \text { industry } \\
\text { associations. } & \end{array}$ & $\begin{array}{l}\text { Legal and infrastructural } \\
\text { support and control over } \\
\text { the implementation of the } \\
\text { objectives of interaction } \\
\text { between business entities } \\
\text { of the regions }\end{array}$ & $\begin{array}{l}\text { Patenting and licensing } \\
\text { of intellectual property } \\
\text { rights and promotion of } \\
\text { national innovative } \\
\text { products on the world } \\
\text { market of intellectual } \\
\text { property }\end{array}$ \\
\hline \multicolumn{4}{|c|}{ System of state support and incentives } \\
\hline $\begin{array}{l}\text { Provision of state } \\
\text { guarantees and favorable } \\
\text { institutional conditions } \\
\text { for stimulation of } \\
\text { innovative business } \\
\text { development. }\end{array}$ & $\begin{array}{l}\text { Regional and state } \\
\text { authorities. }\end{array}$ & $\begin{array}{l}\text { Implementation of target } \\
\text { programs, subprograms } \\
\text { and activities under state } \\
\text { programs. Support of } \\
\text { export, formation of } \\
\text { demand for innovative } \\
\text { products. }\end{array}$ & $\begin{array}{l}\text { State contracting, PPP, } \\
\text { import substitution, etc. }\end{array}$ \\
\hline \multicolumn{4}{|l|}{ System of financial support } \\
\hline $\begin{array}{l}\text { Ensuring the financial } \\
\text { sustainability of } \\
\text { innovative enterprises in } \\
\text { the region, minimizing } \\
\text { risks. }\end{array}$ & $\begin{array}{lr}\text { Banks; } & \text { insurance } \\
\text { companies; } & \text { pension } \\
\text { funds; } & \text { industrial } \\
\text { enterprises; } & \text { research } \\
\text { organizations } & \text { and } \\
\text { institutions; households. }\end{array}$ & $\begin{array}{l}\text { Attracting financial } \\
\text { resources to high-tech } \\
\text { areas; integration in the } \\
\text { global innovation market. }\end{array}$ & $\begin{array}{l}\text { Tax burden; } \\
\text { regimes } \\
\text { taxation; } \\
\text { outsourcing. }\end{array}$ \\
\hline
\end{tabular}


Table 2. Continued

\begin{tabular}{|c|c|c|c|}
\hline \multicolumn{4}{|l|}{ Information support system } \\
\hline $\begin{array}{l}\text { Management } \\
\text { information } \\
\text { analytical ensuring the } \\
\text { innovation process. }\end{array}$ & $\begin{array}{l}\text { Information centers; } \\
\text { scientific and technical } \\
\text { information networks; } \\
\text { business centers; } \\
\text { industrial park } \\
\text { structures; } \\
\text { consulting firms; patent } \\
\text { and license offices. }\end{array}$ & $\begin{array}{l}\text { Exchange of innovative } \\
\text { information; changing } \\
\text { the way of life of the } \\
\text { population of the region; } \\
\text { dissemination of } \\
\text { innovation culture; } \\
\text { minimization of } \\
\text { transaction costs in terms } \\
\text { of information costs and } \\
\text { the scale of exchange. }\end{array}$ & $\begin{array}{l}\text { Creation of horizontal } \\
\text { scientific networks; } \\
\text { transfer of innovative } \\
\text { technologies; } \\
\text { consulting services; } \\
\text { registration of } \\
\text { intellectual property. }\end{array}$ \\
\hline \multicolumn{4}{|l|}{ Research support system } \\
\hline $\begin{array}{l}\text { Realization of priority } \\
\text { directions } \\
\text { development of science } \\
\text { and technology and } \\
\text { innovative activity. }\end{array}$ & $\begin{array}{l}\text { Regional programs of } \\
\text { innovative development; } \\
\text { network of regional } \\
\text { centers of innovative } \\
\text { development. }\end{array}$ & $\begin{array}{l}\text { Ensuring technological } \\
\text { development; interaction } \\
\text { of regional innovation } \\
\text { systems; establishing } \\
\text { tetrad ties "production - } \\
\text { business - science - } \\
\text { education". }\end{array}$ & $\begin{array}{l}\text { State order for } \\
\text { innovative products; } \\
\text { preferential taxation for } \\
\text { companies that } \\
\text { implement innovations; } \\
\text { legal, economic and } \\
\text { political instruments. }\end{array}$ \\
\hline
\end{tabular}

In this case, in the conditions of society's transition to a post-industrial type of economic reproduction, the policy of state regulation of innovative development of the economy is decisive, since modern market mechanisms of self-regulation are unable to independently ensure innovative and technological shifts in the economy. Instead, institutional support by the state of the innovation process is one of the prerequisites for ensuring stable long-term economic growth based on an innovative model of development of the national economy.

Synergistic interaction of the components of the integration mechanism of innovationoriented economic development of the Russian Federation regions should meet the logical sequence of strengthening the role of regional governments in the provision of scientific and technological activities, accompanied by an increase in the demand of economic entities for complex knowledge-intensive products within the global space. It must create a certain integrity, the unity of the regional, national and global innovation space. In this system of coordinates interdependence and interaction of institutional components of the mechanism of innovation-oriented economic development of the regions, namely the mechanism of synergy of innovation processes in the regions of the country should be formed.

Note that in the economically developed countries of the world there is a belief in the need to limit government intervention (both direct and indirect) in the development of market processes and maximum compliance with the principle of market self-regulation. The degree of intervention of state authorities in regulating the structural shifts of the national economy depends on the level of development of the market environment and economic development of the state. The need for state regulation of innovative processes is primarily due to the scale of financial costs of research and implementation of its results, the existence of such processes, which generally cannot be carried out on a commercial basis. For countries with economies in transition, the state or society, rather than individual entrepreneurial structures, especially those that are focused on maximizing profits through rapid capitalization, is primarily responsible for the activation of innovation processes. Thus, in modern conditions, the transformation of the economic system on the basis of innovation and technological development requires increased state action in the management of innovation activity, improvement of organizational, legal, economic and financial mechanisms to ensure innovation activity of the state.

According to the results set out in Table 2, we can decide that one of the tools of innovative development should be considered regional industrial parks. Taking into account the relevance of the growth of innovative activity through the plane of development of 
industrial parks, an analysis of the elements of the mechanism of state support for an industrial park was carried out. The result obtained in the most general form demonstrates that the elements of the mechanism of state support and assistance to the development of industrial parks can be considered in three directions: 1) promoting the development of industrial parks (e.g., state guarantees, development of the provision of legislation, programs to encourage residents and management companies); 2) financial support (e.g., budget financing of industrial park infrastructure development projects; subsidizing innovative projects of residents, etc.); 3) industrial policy of the regions of the Russian Federation in terms of measures to stimulate innovation and investment activity.

The development of global innovation infrastructure leads to the need for the existence of a mechanism of strategic management of the processes of demand for innovation, which subordinates the sequence of stages of determining the innovative activity of business entities and provides for the clarification of each of them specific objectives and levers to stimulate innovation activities of entities in terms of public-private partnership. This largely means the need to find strategic dominants in the development of innovative processes, subject to national economic interests in the global space.

\section{Assessment and Monitoring of the Effectiveness of the Institutional Environment}

It should be noted that the determining criteria for the effective functioning of the institutional environment of innovation activity can be considered: the criterion of social and macroeconomic stability, improvement of the quality of socio-economic institutions. According to the estimates of the World Bank experts, an increase in the quality of institutions of the national economy system by $1 \%$ allows to increase economic growth rates by $1.4 \%$, and an increase in the level of financial sector development by $1 \%$ increases economic growth rates by only $0.5 \%$ [9]. That is, the system of institutional support of innovative development can significantly affect both economic growth and the transformation of socio-economic systems in the direction of the consolidation of intellectual property rights, creating conditions for the growth of market demand for innovation, the effective functioning of the market of products of intellectualization, promoting the development of a competitive environment.

Let us note that in the modern conditions of the globalization process, the evaluation of the quality of institutional development of the national economy is carried out on the basis of the methodology for analyzing the efficiency of the functioning of institutions developed by V. Zotov, who suggests that the quality of functioning of institutions (K) should be determined by the formula [10, p. 125]:

$K=\sum_{i=1}^{n} \alpha_{i} A_{i} R_{i} E_{i}$, (1)

where $A_{i}$ is the coefficient of adequacy of the $i$-goal of functioning of the institute, $i=$ $\overline{1, n} ; R_{i}$ is the coefficient of performance of the $i$-goal of the institute's functioning, $i=\overline{1, n}$; $E_{i}$ is the coefficient of efficiency of the $i$-goal of the institute's functioning, $i=\overline{1, n} ; \alpha_{i}$ is the coefficient of the $i$-goal of the functioning of the institute.

In the proposed model, the coefficient of adequacy of the institute is based on an assessment of the level of compliance with the goals (C), the achievement of which should ensure the created institution based on public needs $(\mathrm{P})$, or $\mathrm{A}=\mathrm{C} / \mathrm{P}$.

The coefficient of performance of the institute is understood as an assessment of the level of compliance of the obtained result $(\mathrm{X})$ with the set goals $(\mathrm{C})$, that is, $\mathrm{P}=\mathrm{X} / \mathrm{C}$.

Efficiency coefficient is an estimate of the cost capacity of the created institution, i.e. is the ratio of the result $(X)$ to the costs of achieving it $(Z): E=X / Z$.

The above model does not reflect the temporal parameter of the quality of institutions and the dynamics of institutional shifts, which makes it impossible to carry out a reliable 
assessment of the quality of the institutional basis of the economic system and necessitates the construction of a triad model of institutional quality, taking into account the time factor. Then formula (1) should be clarified, taking into account the fact that the resources to support or implement an institutional technology can be not only financial, but also temporary:

$$
K=\sum_{i=1}^{n} \alpha_{i}\left(\frac{\mathrm{C}_{i}}{P_{i}}\right)\left(\frac{X_{i}}{C_{i}}\right)\left(\frac{X_{i}}{\sum_{j=1}^{n} \beta_{j} Z_{i j}}\right) \text {, (2) where } \beta_{j} \text { is the price of the resource. }
$$

The post-transformation stage of economic development is characterized by a high level of vagueness of the norms and rules of conduct of formal and informal nature, the lack of perfection of their regulation, which, in turn, gives rise to uncertainty. In particular, the evaluation of the effectiveness of indistinct, incomplete institutions can be carried out through the concept of institutional entropy, introduced by the founder of the synergetic approach in economics H. Haken: $I=-\sum_{j=1}^{n} p_{j} \ln p_{j}, p_{j}$ is probability of $j$-event in the functioning of the institute, $j=\overline{1, n}$.

It is worth noting that assessing the quality of institutions on the basis of institutional entropy involves only a quantitative approach, where quantitative indicators of the goals are reflected and compared with the actual values. If specific parameters are not clearly measurable or not quantifiable at all (behavioral, motivational norms, ethical-moral, spiritual factors, historical and cultural preconditions), the application of this methodology excludes assessments of the institutional basis of the economy.

In this regard, the question of developing a methodology for both quantitative and qualitative assessment and diagnosis of the formation of the institutional environment of innovative development becomes relevant. At the basis of its solution is the creation of a process model of such a mechanism, the main elements of which should perform the functions: 1) mapping of institutional factors, their identification in the processes of innovation activity; 2) identification of institutional factors associated with the main barriers to innovation; 3) installation and diagnosis of gaps, defects, deformations of the institutional system of innovative activity; 4) revealing system defects in the formation and impact of institutional factors of innovation activity; 5) determination of measures aimed at elimination of defects in institutional support of innovation activity; 6) monitoring and evaluation of the effectiveness of the measures taken.

Full functioning of the elements of the above mechanism will allow to solve problems in the context: 1) improving the institutional and methodological support of innovative development processes; 2) development of strategic imperatives of innovative development, as well as evaluation of management decisions taken; 3) analysis and elimination of contradictions resulting from the transformation and deformation of institutions. The main factors driving this mechanism are the variety of changes in the external and internal processes of institutional development.

\section{Conclusion}

Despite the presence of significant potential for the development of scientific-technological and innovation activities in the Russian Federation, there is still insufficiently high rate of overcoming the technical and technological backwardness of the real sector, as well as a low level of innovative industrial production, which in an excellent way hinders the development of the digital economy.

The work establishes that the conceptual framework for the formation of institutional environment should be considered as one of the key factors for the effective functioning of the market environment. Institutional factors of innovative activity development have dual essence: firstly, they strengthen the positive influence on strengthening of innovative 
activity of the state, secondly, they are designed to overcome or minimize the risks of innovative activity.

The above circumstances should be reflected in the development of the integration mechanism of innovative development of the Russian Federation. According to the authors, its components are systems of support for the initial development of innovative projects, state support and incentives, organizational, financial, informational, research support. These constituent elements form a certain integrity, the unity of the regional and national space.

\section{Results discussion}

In our opinion, the determining role in promoting innovative and technological shifts of the national economy should belong to the state, which creates favorable conditions for the development of innovative activity, forming uniform transparent and clear principles, rules and mechanisms to improve the functioning of the subjects of innovative activity. However, today there are many legal, methodological and other institutional problems that prevent the effective functioning of these processes, which predetermines the further extensive consideration of this problem by the scientific community.

\section{References}

1. T. Veblen, Theory of the leisure class, 367 (1984)

2. J.K. Galbraith, New industrial society: selected, 302 (2008)

3. D. North, Institutions, institutional changes and the functioning of the economy, 188 (1997)

4. K. Menard, Economics of organizations, 160 (1996)

5. L.I. Abalkin, Logic of economic growth, 228 (2002)

6. H. H. Lebedeva, Institutional mechanism of the economy: essence, structure, development, 231 (2002)

7. G.V. Kolodko, Globalization and development prospects of post-socialist countries, 200 (2002)

8. B. Carroll Archie, A. Buchholtz, Business and Society: Ethics and Stakeholder Management, 750 (2000)

9. Growth and Institutions, Word Development Report, 3, 98 (2003) http://www.worldbank./

10. V.B. Zotov, The system of municipal management, 546 (2006)

11. O.V. Inshakov, D.P. Frolov, The Economist, 7, 39 (2005)

12. Z. Rong, X. Wu, P. Boeing, Research Policy, 46(9), 1533 (2017)

13. E. Thun, Technovation, 70-71, 7 (2018)

14. K.K. Kurbanova, P.S. Yunusova, Regional problems of economic transformation, 5, 5 (2018) 